\title{
Gamethinking: a roadmap to a Design Thinking- based model for Game Development education
}

\author{
Farley Fernandes, Américo Mateus, Susana \\ Leonor, Manuel Sequeira \& Rui Gaio
}

\begin{abstract}
The mindset, behavior, and attitude of students in game development, project-based learning (PBL) B.Sc.'s towards the creative processes has proven to be a barrier with regards to the need to increase of the creativity of the student's project proposals. While it is true that a systematic use of Design Thinking (DT) throughout the curriculum would certainly improve the situation, a different approach is clearly needed, most likely an approach that combines DT with gamification, and that makes optimal use of project-based learning (PBL) using agile methods. In order to refine and clarify our possible contribution on the conjunction of such perspectives, we conducted an initial literature review that validated our objectives. Complementarily, we also defined a roadmap to transform such intentions into practical actions towards the creation of a new game development model based on DT principles. This whole definition is based on IDEAS(R)EVOLUTION methodology, which gives structure for the research on the long run.
\end{abstract}

Keywords:

design thinking; project-based learning; agile; gamification 


\title{
Gamethinking: um roadmap para um modelo baseado em design thinking para a educação em desenvolvimento de jogos
}

\begin{abstract}
Resumo: O mindset, comportamento e postura de alunos de licenciatura em desenvolvimento de videojogos integrados em sistemas de aprendizagem baseados em projecto têm-se revelado uma barreira à criatividade das suas propostas de projects, mais especificamente no que diz respeito a processos criativos. Ao passo que a utilização sistemática do Design Thinking (DT) ao longo do currículo escolar certamente melhoraria a situação. Uma abordagem diferente é claramente necessária, muito provavelmente uma que combine DT com gamificação, e que faça uma utilização apropriada da aprendizagem baseada em projeto (PBL) com os métodos ágeis. De forma a refinar e clarificar a nossa contribuição na conjunção destas perspetivas, conduzimos uma revisão da literatura inicial que validou os nossos objetivos. Complementarmente, também definimos um roadmap para transformar tais intenções em acções práticas para a criação de um novo modelo de desenvolvimento de videojogos baseado nos princípios do DT. Toda a definição é baseada na metodologia IDEAS(R)EVOLUTION, a qual provê uma estrutura para toda a investigação no longo prazo.
\end{abstract}

Palavras-chave: design Thinking; aprendizagem baseada em projeto; agile; gamificação

\section{Gamethinking: une roadmap pour un modèle fondé sur design thinking pour l'éducation au development du jeu}

Résumé: L'état d'esprit, le comportement et la posture des étudiants de premier cycle dans le développement de jeux vidéo avec l'apprentissage par projet en relation avec les processus créatifs a été une barrière dans le sens de la créativité croissante dans leurs propositions de projets. Alors que l'utilisation systématique de Design Thinking (DT) à travers le programme scolaire améliorerait certainement la situation, une approche différente est clairement nécessaire, très probablement celle qui combine la TD avec la ludification et fait un usage approprié de l'apprentissage par projet (PBL) ) avec des méthodes agiles. Afin d'affiner et de clarifier notre contribution en conjonction avec ces perspectives, nous avons effectué une revue de la littérature initiale validant nos objectifs. En outre, nous avons également défini une feuille de route pour transformer ces intentions en actions pratiques pour la création d'un nouveau modèle de développement de jeux vidéo basé sur les principes DT. La définition complète est basée sur la méthodologie IDEAS(R)EVOLUTION, qui fournit une structure pour toutes les recherches à long terme.

Mots clé: design thinking; apprentissage par projet; agile; gamification

\section{Gamethinking: un roadmap para un modelo basado en el Design Thinking para la educación en desenvolvimento de videojuegos}

Resumen: El mindset, comportamiento y postura de alumnos de licenciatura en el desarrollo de videojuegos con aprendizaje basado en proyecto en relación a procesos creativos, se ha mostrado una barrera para aumentar la creatividad en sus propuestas de proyectos. Mientras que el uso sistemático del Design Thinking (DT) a través del currículo escolar ciertamente mejoraría la situación, un enfoque diferente es claramente necesario, muy probablemente uno que combine DT con gamificación, y que haga un uso apropiado del aprendizaje basado en proyectos $(\mathrm{PBL})$ con los métodos ágiles. Con el fin de refinar y aclarar nuestra contribución en la conjunción de estas perspectivas, conducimos una revisión de la literatura inicial que validó nuestros objetivos. Complementariamente, también definimos un roadmap para transformar tales intenciones en acciones prácticas para la creación de un nuevo modelo de desarrollo de videojuegos basado en los principios del DT. Toda la definición se basa en la metodología IDEAS(R)EVOLUTION, la cual proporciona estructura para toda la investigación a largo plazo.

Palavras-chave: design thinking; aprendizaje basado en proyectos; agile; gamification 


\section{Introduction}

Far from having a consolidated definition, gamification can be defined as the application of game elements to non-game contexts (Seaborn \& Fels, 2015). At the same time, these researchers conducted an in-depth meta-analysis to unveil multiple perspectives from the concept, coming to find several related historical definitions like: funware, funology, serious games, among others.

Gamification is frequently used when referring to software mediated user interaction that include game design elements in its core and, occasionally, also outside the realm of human-computer interaction. Albeit having several discussions over its definition, one point of agreement resides in the idea that any gamified experience embracing ludic elements should be different from a game situation independently of whichever game definition adopted (Deterding, Dixon, Khaled, \& Nacke, 2011).

If we shall consider a ludological approach to the study of the gamification phenomenon in game development education, we must consider the nature of the acts that are promoted in that specific context and the impact these might have on the mindset of students and others involved. Thus, our observations should focus more on the possible interceptions between the participant's experiences and play, not so much on the intrinsic characteristics of the educative methods.

Towards a more huizinguian ${ }^{1}$ approach, we are not so much focused on play versus game, but as educational activities that welcome players and motivates them to enjoy a deep sense of freedom offered by play.

We are interested in delving into latest developments regarding the conjunction of Design Thinking and Gamification to investigate under specific criteria what has been the research focus and results so far, consequently this enables us to position and differentiate our research in terms of the contribution to be achieved. From this basic review, we expect to form the building blocks to develop a Design Thinking methodology tailored for game development and gamified solution.

\section{Justification}

Our point of departure is the fact that gamified projects are expected to fail $80 \%$ of the time, curiously, due to bad (game) design. In this sense, we propose that Gamification and Design Thinking (DT) have a lot do and contribute with each other as the disciplines are mostly interested in understanding a specific context and proposing innovative solutions. Albeit having the common ground of Design (as a scientific field), each one acts on their own terms as they come and form distinct ramifications within this major domain. Gamification is mostly interested in motivating or creating certain behaviours in a specific setting, this is achieved through solutions that applies game 
elements. Design Thinking, for its turn, intends to approximate designers and non-designers from several fields in order to amplify team perspective while solving a specific problem. It is time to open a conversation and see a better fit in merging both areas.

There is enough diversity and quantity among gamification methodologies that justifies the interest for the theme to be further investigated (Mora, Riera, Gonzalez, \& Arnedo-Moreno, 2015). Some initiatives even intends to create their own gamification methodologies from scratch by applying scientific research methods like: action design research or design science research (Klapztein \& Cipolla, 2016; Morschheuser, Hamari, Werder, \& Abe, 2017), companies have also been developing their own tools and methods to gamify their solutions (Arnab, Nalla, Harteveld, \& Lameras, 2015).

There is enough diversity and quantity among gamification methodologies that justifies the interest for the theme to be further investigated (Mora et al., 2015). Some initiatives even intends to create their own gamification methodologies from scratch by applying scientific research methods like: action design research or design science research (Klapztein \& Cipolla, 2016; Morschheuser et al., 2017).

Complementarily, companies have also been developing their own commercial tools and methods to gamify solutions, be it a product or a service (Arnab et al., 2015). These authors were able to classify theses proprietary methodologies and found that they comprise the following phases to which it is possible to find strong relationship to Design Thinking methodologies:

"(1) Understand the business objectives and define more specific goals; (2) Define the behaviors that will lead to business objectives; (3) Understand the target audience or players; (4) Apply game mechanics according to the player types and desired behaviors; and (5) Analyze behaviors, measure results and optimize accordingly, in order to achieve success in applying gamification in business"

Accordingly, the methodology Services \& Products Gamified Design (SPGD) (Signoretti, Martins, Rodrigues, Campos, \& Teixeira, 2016) extends and adapts an existing DT methodology called Design Thinking Canvas².

\section{Literature review}

In order to locate our contribution and develop an overall landscape, we carried out an initial literature review aimed at qualifying recent studies (less than 3 years). The objective was to refine our perspective on merging DT and gamification (See Table 1). This was done applying the following criteria:

- Context: if the application was carried in commercial or academic environment. 
- Relationship to Design Thinking: uses, adapts or is inspired by any existing DT methodology or undefined if it does not reference any specific methodology.

- Output: creates a product, service or fosters behavioral change.

\begin{tabular}{|c|c|c|c|c|c|}
\hline TITLE & AUTHOR & YEAR & CONTEXT & $\begin{array}{l}\text { RELATION } \\
\text { TO DT }\end{array}$ & OUTPUT \\
\hline $\begin{array}{l}\text { Octalysis - complete } \\
\text { Gamification framework }\end{array}$ & Chou & 2015 & Commercial & undefined & $\begin{array}{l}\text { service or } \\
\text { behavior }\end{array}$ \\
\hline $\begin{array}{l}\text { Gamification in Education } \\
\text { Through Design Thinking }\end{array}$ & $\begin{array}{l}\text { Sombrio, } \\
\text { Schimmelpfeng, } \\
\text { Ulbricht, \& } \\
\text { Villarouco }\end{array}$ & 2016 & Academic & adapt & product \\
\hline $\begin{array}{l}\text { From Game Design } \\
\text { to Service Design: A } \\
\text { Framework to Gamify } \\
\text { Services }\end{array}$ & $\begin{array}{l}\text { Klapztein \& } \\
\text { Cipolla }\end{array}$ & 2016 & Academic & undefined & service \\
\hline $\begin{array}{l}\text { Towards Meaningful } \\
\text { Engagement:A Framework } \\
\text { for Design and Research } \\
\text { of Gamified Information } \\
\text { Systems }\end{array}$ & $\begin{array}{l}\text { Liu, Santhanam, } \\
\text { \& Webster }\end{array}$ & 2016 & Academic & undefined & product \\
\hline $\begin{array}{c}\text { Services \& Products } \\
\text { Gamified Design (SPGD) } \\
\text { A Methodology for Game } \\
\text { Thinking Design }\end{array}$ & Signoretti et al. & 2016 & Academic & adapt & $\begin{array}{l}\text { product } \\
\text { or service }\end{array}$ \\
\hline $\begin{array}{l}\text { How to gamify? A method } \\
\text { for designing gamification }\end{array}$ & $\begin{array}{l}\text { Morschheuser } \\
\quad \text { et al. }\end{array}$ & 2017 & Academic & inspired & $\begin{array}{l}\text { product } \\
\text { or service }\end{array}$ \\
\hline $\begin{array}{c}\text { An Inquiry into Gamification } \\
\text { Services: Practices, } \\
\text { Experiences and Insights }\end{array}$ & Arnab et al. & 2015 & Commercial & undefined & $\begin{array}{l}\text { service or } \\
\text { behavior }\end{array}$ \\
\hline $\begin{array}{l}\text { Business Model Design } \\
\text { Games: Rules and } \\
\text { Procedures to Challenge } \\
\text { Assumptions and Elicit } \\
\text { Surprises }\end{array}$ & Gudiksen & 2015 & Commercial & inspired & $\begin{array}{l}\text { product } \\
\text { or service }\end{array}$ \\
\hline $\begin{array}{l}\text { A literature review of } \\
\text { gamification design } \\
\text { frameworks }\end{array}$ & Mora et al. & 2015 & Academic & undefined & $\begin{array}{l}\text { product, } \\
\text { service or } \\
\text { behavior }\end{array}$ \\
\hline $\begin{array}{l}\text { A theory of work } \\
\text { gamification: Something } \\
\text { old, something new, } \\
\text { something borrowed, } \\
\text { something cool? }\end{array}$ & $\begin{array}{l}\text { Cardador, } \\
\text { Northcraft, \& } \\
\text { Whicker }\end{array}$ & 2017 & Academic & undefined & $\begin{array}{l}\text { product, } \\
\text { service or } \\
\text { behavior }\end{array}$ \\
\hline
\end{tabular}

Table 1. Summarization of related works merging Design Thinking and Gamefication methodologies 
To conclude our initial analysis, these are our main takeaways:

- Most of the results obtained are still in academic setting, which means that most of the models have yet to be validated within market solutions.

- Regarding Design Thinking integration, we still find a very weak link. Although it is an initial and brief review, to our best intent we could not find a Design Thinking methodology tailored specifically to the needs of gamification.

- From the outputs expected, service solutions dominate being closely followed by product creation. Although we did not qualify for now, we also could not find a strong link to game creation itself.

The proposition of creating and validating a new Design Thinking model that is specifically tailored to create games and gamified solutions seems to be a relevant contribution within this domain. This can certainly impact in several contexts of application from education to addressing more innovative market solutions.

\section{Learning context on the triad of agile, gamification and project-based learning: a discussion}

Since the launch of Agile Manifesto ${ }^{3}$, agile methodologies have been largely adopted and developed in educational and commercial sectors. Due to this extensive usage, agile methodologies are significantly important to innovative companies nowadays, thus it is important to analyse how they have been integrated with gamification tools as well. "Iteration is a core hallmark of agile design. In truth, agile and gamification have a lot in common-they both profess that any concept in a system requires repeated testing," according to Zichermann and Cunningham (2011). Considering the integration of gamification with software development including agile, there is still a need to go further on game features to be integrated as most of the time only basic ones are employed (e.g. badges and points) and very few studies provides empirical evidence of their impact on organizational setting (Pedreira, García, Brisaboa, \& Piattini, 2015).

While applying gamification principles in agile setting, it is extremely important to make clear how reputation is scored as this is the most correlated factor to performance improvement (Prause, Nonnen, \& Vinkovits, 2012). Some initial results show that the application of gamification within agile projects helps to improve the collaboration between product owners and development teams (Konieczny, 2015) and productivity (M. Pereira, J.P. Amorim, A. Cota, \& C. Gonçalves, 2017), overall this might help addressing the main pillars of Agile Manifesto.

As an overall objective, our research intends to use Design Thinking approach to combine and translate these benefits for the creation of new models for existing 
educational modules. Considering the most suitable skills for 21 st century, game-based learning approach might be effective in facilitating students' development on those (Qian \& Clark, 2016). This review also revealed that, for this approach, the most used learning theory is constructivism and the most impacting features on students' outcomes from game design are: competition, collaboration and exploration \& discovery. It is important to recognize the linkage between game mechanics, dynamics and motives to explore gamification to its full potential (see figure 1). Students involved in this kind of context report an improvement of their capacities (Mercer et al., 2017). This study also found that design thinking and learning by design helped student to integrate values and cognitions important to Educational Sustainable Development (ESD). The matter of individual engagement and consequent recognition of own actions becomes more explicit through gamification as students respond positively to that by showing higher indexes on factors like: teamwork, questioning, cooperation, autonomy, among others (da Rocha Seixas, Gomes, \& de Melo Filho, 2016).

Considering the so much discussed migration of theory-based to a more effective practice-based of the learning environment, it is cautionary to recognize and try to avoid the possibility of game elements being recognized only as extrinsic motivators due to their incapacity of increasing quality of the expected outcomes in some contexts (Mekler, Brühlmann, Tuch, \& Opwis, 2015). In a different gamified context, similar results of quality versus quantity on student participation were shown by (Denny, 2013). This of utter importance, as the expansion (or redefinition) of students' role in learning environment means that they will be required to perform on several "new tasks". On this new perspective, while fostering peer assessment for example, gamification features have had a reportedly positive effect overall on students participation (Tenório, Bittencourt, Isotani, Pedro, \& Ospina, 2016).

\begin{tabular}{|c|c|c|}
\hline \multicolumn{2}{|l|}{ Game-design elements } & \multirow[t]{2}{*}{ Motives } \\
\hline Game mechanics & Game dynamics & \\
\hline Documentation of behavior & Exploration & Intellectual curiosity \\
\hline Scoring systems, badges, trophies & Collection & Achievement \\
\hline Rankings & Competition & Social recognition \\
\hline Ranks, levels, reputation points & Acquisition of status & \\
\hline Group tasks & Collaboration & Social exchange \\
\hline Time pressure, tasks, quests & Challenge & Cognitive stimulation \\
\hline Avatars, virtual worlds, virtual trade & Development/organization & Self-determination \\
\hline
\end{tabular}

Figure 1 - Game design elements to motives linkage (Blohm \& Leimeister, 2013) 


\section{Roadmap to develop gamethinking model}

Overall, we can see that creating a new model based on Design Thinking and Gamification can prove valuable. This paper is part of an ongoing research initiative, whose objective is the creation of a new pedagogical model that will most likely combine DT with gamification, also it will make optimal use of project-based learning (PBL) and agile methods.

This research is thus focused on constructing a new pedagogical model, field testing it, and disseminating it so that it can be applied to today's and future game development B.Sc.'s. This new model, named Gamethinking, aims at using DT as more than a creativity process, but also as a changer of the culture, mindset, and behavior of game development students, addressing issues such as cognitive models, belief systems, and learning behavior through gamification and ludology fundamentals.

The overall research framework for model creation is based on IDEAS(R)EVOLUTION methodology (A. da C. Mateus, 2016) a validated experimental research methodology and process that combines the model building, action research, and living lab research methods. This innovation methodology will be implemented as a study macro-process, with micro-processes related to the execution of tasks and activities.

The six stages of IDEAS(R)EVOLUTION correspond to the phases of overarching research project:

1. Literature review / involvement

2. Analysis of existing models and tools / inspiration

3. Model design / ideation

4. Model building / integration

5. Pilot and validation / implementation

6. Results and dissemination / interaction

7. The first phase, literature review (involvement), is about diagnosing and surveying. A thorough literature review of the relevant scientific results from the areas of psychology, education, active pedagogical methods, DT, ludology, gamification, and agile software development will be conducted. This will allow us to better understand the methodologies and tools applicable, and whether they have proven to be effective in solving the identified problem. Our aim is to understand deeply the role played by experience, belief systems, and cognitive models in the formation of the barriers faced by game development students, and the methods that can be used reduce them. Since the barriers faced by the students are not unique, the review will not focus exclusively in education: we expect insights to be gained from other areas, including the game development industry and the development industry in general. This will help us later to propose a new educational model for eliminating or at the very least greatly mitigating these barriers, thus leading to B.Sc. programs where students can make full use the creative process, and their own potential, in game development. 
8. The second phase, analysis of existing models and tools (inspiration), is about understanding and defining which factors the help address our overall objective. We will perform and in-depth analysis of existing academic, pedagogical, and commercial DT, gamification, PBL, and agile development models and tools applicable to game development education. Existing models will be analyzed and their potential for total or partial integration into a new pedagogical model will be ascertained.

This second phase will consist in several field studies, including observations and deep immersion in relevant settings, deep interviews with the academic partners, and benchmarking of the best professional practices. During this phase, we will conduct fieldwork missions using observation techniques as well as in-depth surveys, to retrieve information. A set of mixed methods and techniques will be used to obtain quantitative and qualitative data. The perceived values of the activities will be analyzed and the critical success factors will be identified. This will provide us with a comprehensive understanding about the most relevant topics, which will lead to the development of a set of best-practices and other information to be used in later phases of the project.

The third phase, model design (ideation), is a co-creative process. The objective of this phase is to obtain a good set of ideas for what the new pedagogical model will be. We will implement a series of fieldwork co-design workshops with experts from industrial (agile software developers, game developers, and Scrum Masters) and academic (students, lecturers, and researchers) backgrounds. These workshops will ascertain the study's representativeness and validate its results. The experts will come from a wide range of backgrounds: designers, design schools, faculty, businesses, leaders, opinion makers, legislators, trend setters, students, researchers, users, and consumers. The co-design workshops will include ideation, experimentation, and consensus, as well as creative tools and techniques developed by the research group and widely published (A. da C. Mateus, 2016; A. Mateus, Rosa, Leonor, \& Loureiro, 2012; Americo Mateus, Ferreira, \& Gomez, 2010).

From the understanding gained in the previous phases, in the fourth phase, model building (integration), we will conduct gap analysis ${ }^{4}$ and Delphi ${ }^{5}$ consensus rounds sessions aimed at co-creating the first iteration of the new pedagogical model by finding the right combination and interplay of elements from DT, gamification, PBL, and agile development, that can lead to significant improvements in game development education. We will obtain valid data from the ideas for the new model generated in the previous phase. The most promising ideas, practices, parameters, and principles will be submitted to Delphi consensus rounds and further presented to evaluation by an external group composed, by triangulation, of three stakeholder panels: students (makers), lecturers (education experts), and professionals (game developers). The gap analysis technique will allow us to find commonalities, as well as divergences, between these panels. The main objective is to obtain data about the perceived value 
of our pre-conceptual model. At the end of this process, three Delphi rounds will be performed to close gaps and reduce divergence, and thus generate consensus. The TRIZ technique (Chai, Zhang, \& Tan, 2005) will be used in hard to reach consensual solutions. This research will enable us to improve and design the new model, including practices, pedagogy, methodology, and tools.

After the new model is built, it must be tested, refined, and validated. This is the purpose of the fifth phase, pilot and validation (implementation). For this phase, the testbed / living lab methodology will be used, first by applying the new model into a simulation of the learning environment of the game development B.Sc.'s, and later, after the improvements from the pilot tests, by applying it as a proof of concept living lab (Bergvall-Kareborn \& Stahlbrost, 2009). The main objectives are to test the final concepts, generate the final conceptual model, and to develop a best practices manual.

The living lab methodology will be applied for a semester to develop an initial case study. Its design will be the following: (a) select participants; (b) train them and provide them the best practices manual; (c) ensure the same working conditions for all participants; (d) observe implementation and development, registering the applied processes, practices, and methodologies; (e) ask participants to implement the game proposal generated in the previous tasks; and ( $\mathrm{f}$ ) analyze the experimental data and apply a survey to assess the increase in the participants' knowledge and skills.

Finally, during the last phase of the project, results and dissemination (interaction), is where the results are analyzed, conclusions are drawn, and findings are disseminated. The most direct form of dissemination is the application of the new models in game development B.Sc.'s programs. This will allow further studies to continue in the long run and more results to be disseminated in the future. Dissemination will include submission of articles to relevant journals and conferences, publication of books, presentation of findings in international scientific conferences (regular papers and keynotes), presentation of results in professional game development conferences and meetings, and workshops in other universities offering B.Sc.'s in game development.

\section{Conclusion}

The work laid out here stands as an initial roadmap for a larger research conducted by the authors in order to address the need for a new model for game development educational programs. The result presented is twofold: a clear justification that the proposition for a new model is valid for the context intended and a structured script for the construction of such model. The whole sequence of activities proposed is yet to be executed, but they are all based on consolidated creative methods. The next step is to further develop this study and later assess the level of adherence regarding Gamefication and Design Thinking objectives. 
In terms of this proposed conjunction, we showed that, there is no representative model or methodology that addresses specifically game development processes. Considering the multitude of existing applications from Design Thinking and Gamification, this represents a gap, especially as those share some commonalities that might indeed prove useful. Therefore, the use of Design Thinking for game development is an advance for Design as a scientific discipline. In addition to that, we also embed the context of our initiative with agile and project-based learning as these fields can offer a more practical and flexible approach for project development.

As future work, our research will evolve to a more operational direction, consisting of the six phases described in the previous section towards the creation of Gamethinking model. The expected output is that this conceptual model for game development which will serve both academic and commercial sectors. As previously described, the model will be field-tested to build a real case study on an existing educational program.

Overall, the most important aspect to be evaluated on this initial case study is to check whether participant game developers will be able to detach themselves from consolidated game references and cases or not, as this might limit innovative capacity in their results. This is especially critical on initial phases, when developers are still defining their game concepts, most of the time their main constraint is made only by technical aspects.

Gamethinking model must counter this unintended effect by shifting the focus at outset and enabling a new rational between game mechanics and aesthetics (and all it encompasses) to put on MDA Framework terms ${ }^{6}$.

Finally, our research group expects to report the results and disseminate the resulting model so that it can potentially reach out to other stakeholders from game development segment.

\section{Notes}

1 Johan Huzinga is a widely referenced author that, among other topics, studied the aspects and importance of ludicity and play within human behaviour.

2 Design Thinking Canvas is a methodology for product creation developed at Universidade Federal de Pernambuco within GDRLab research group, it combines game aspects with consolidated innovation methods.

3 Agile Manifesto developed by Beck et. al in 2001 is a compilation of principles that guide agile methodologies until this day.

4 Gap analysis is a widely used technique to compare performances (actual and desired).

5 Delphi is a forecasting technique employed by a board of expert in order to reach consensus

6 MDA is a Framework developed by Hunicke LeBlacn and Zubek that conceptualizes a game in three levels: mechanics, dynamics and aesthetics. 


\section{References}

Arnab, S., Nalla, M., Harteveld, C., \& Lameras, P. (2015). An inquiry into gamification services: Practices, experiences and insights. In Proceedings of the International Gamification for Business Conference 2015 (pp. 34-45). Retrieved from http://eprints.aston.ac.uk/27322/1/International_Gamification_ for_Business_Conference_2015_IGBC15_.pdf\#page=40

Bergvall-Kareborn, B., \& Stahlbrost, A. (2009). Living Lab: an open and citizen-centric approach for innovation. International Journal of Innovation and Regional Development, 1(4), 356-370.

Blohm, I., \& Leimeister, J. M. (2013). Design of IT-Based Enhancing Services for Motivational Support and Behavioral Change. Retrieved from http://search.proquest.com/openview/e2c77c0bf1f8c77b2 9c46bf7925d78c1/1?pq-origsite=gscholar\&cbl=816386

Chai, K.-H., Zhang, J., \& Tan, K.-C. (2005). A TRIZ-based method for new service design. Journal of Service Research, 8(1), 48-66.

Chou, Y. (2015). Actionable Gamification: Beyond Points, Badges, and Leaderboards. Octalysis Media.

da Rocha Seixas, L., Gomes, A. S., \& de Melo Filho, I. J. (2016). Effectiveness of gamification in the engagement of students. Computers in Human Behavior, 58, 48-63.

Denny, P. (2013). The effect of virtual achievements on student engagement. In Proceedings of the SIGCHI conference on human factors in computing systems (pp. 763-772). ACM. Retrieved from http://dl.acm.org/citation.cfm?id=2470763

Deterding, S., Dixon, D., Khaled, R., \& Nacke, L. (2011). From game design elements to gamefulness: defining gamification. In Proceedings of the 15th international academic MindTrek conference: Envisioning future media environments (pp. 9-15). ACM.

Klapztein, S., \& Cipolla, C. (2016). From game design to service design: A framework to gamify services. Simulation \& Gaming, 47(5), 566-598.

Konieczny, M. (2015). Gamified Agile Innovative tool to improve communication between Product Owner and the development team. Retrieved from http://cmconference.wzks.uj.edu.pl/wp-content/ uploads/2015/10/296.pdf

M. Pereira, I., J.P. Amorim, V., A. Cota, M., \& C. Gonçalves, G. (2017). Gamification Use in Agile Project Management: An Experience Report. In T. Silva da Silva, B. Estácio, J. Kroll, \& R. Mantovani Fontana (Eds.), Agile Methods (Vol. 680, pp. 28-38). Springer International Publishing. https://doi. org/10.1007/978-3-319-55907-0_3

Mateus, A. da C. (2016). Product/Brand co-creation methodology crossing marketing, design thinking, creativity and management: ideas ( $r$ ) evolution.

Mateus, A., Ferreira, A., \& Gomez, L. (2010). IDEAS(R)EVOLUTION - Transdisciplinary design thinking workshops for remarkable and innovative brand value. In Cumulus Conference. Genk, Belgium.

Mateus, A., Rosa, C. A., Leonor, S., \& Loureiro, A. L. (2012). PPEC 2011-2012: Medida“ Painel de consumidores em redes inteligentes." User Centered Innovation Program-Diagnóstico, Co-Criação, Estratégia Experimentação. Évora. 
Mekler, E. D., Brühlmann, F., Tuch, A. N., \& Opwis, K. (2015). Towards understanding the effects of individual gamification elements on intrinsic motivation and performance. Computers in Human Behavior. Retrieved from http://www.sciencedirect.com/science/article/pii/S0747563215301229

Mercer, T. G., Kythreotis, A. P., Robinson, Z. P., Stolte, T., George, S. M., \& Haywood, S. K. (2017). The use of educational game design and play in higher education to influence sustainable behaviour. International Journal of Sustainability in Higher Education, 18(3), 359-384. https://doi.org/10.1108/ IJSHE-03-2015-0064

Mora, A., Riera, D., Gonzalez, C., \& Arnedo-Moreno, J. (2015). A literature review of gamification design frameworks. In Games and Virtual Worlds for Serious Applications (VS-Games), 2015 7th International Conference on (pp. 1-8). IEEE. Retrieved from http://ieeexplore.ieee.org/abstract/ document/7295760/

Morschheuser, B., Hamari, J., Werder, K., \& Abe, J. (2017). How to gamify? A method for designing gamification. In Proceedings of the 50th Hawaii International Conference on System Sciences. Retrieved from http://scholarspace.manoa.hawaii.edu/handle/10125/41308

Pedreira, O., García, F., Brisaboa, N., \& Piattini, M. (2015). Gamification in software engineering - A systematic mapping. Information and Software Technology, 57, 157-168. https://doi.org/10.1016/j. infsof.2014.08.007

Prause, C. R., Nonnen, J., \& Vinkovits, M. (2012). A field experiment on gamification of code quality in agile development. Citeseer. Retrieved from http://citeseerx.ist.psu.edu/viewdoc/download?doi=10 1.1.394.4187\&rep=rep1\&type=pdf

Qian, M., \& Clark, K. R. (2016). Game-based Learning and 21st century skills: A review of recent research. Computers in Human Behavior, 63, 50-58.

Seaborn, K., \& Fels, D. I. (2015). Gamification in theory and action: A survey. International Journal of Human-Computer Studies, 74, 14-31.

Signoretti, A., Martins, A. I., Rodrigues, M., Campos, A., \& Teixeira, A. (2016). Services \& Products Gamified Design (SPGD): A Methodology for Game Thinking Design. In Proceedings of the 7th International Conference on Software Development and Technologies for Enhancing Accessibility and Fighting Info-exclusion (pp. 62-68). ACM. Retrieved from http://dl.acm.org/citation.cfm?id=3019953

Tenório, T., Bittencourt, I. I., Isotani, S., Pedro, A., \& Ospina, P. (2016). A gamified peer assessment model for on-line learning environments in a competitive context. Computers in Human Behavior, 64, 247-263. https://doi.org/10.1016/j.chb.2016.06.049

Zichermann, G., \& Cunningham, C. (2011). Gamification by Design: Implementing Game Mechanics in Web and Mobile Apps. O'Reilly Media, Inc. 
Farley Fernandes

UNIDCOM / Universidade da Beira Interior

Lisboa, Portugal

Email: fmmf@ubi.pt

ORCID:0000-0002-8573-8877

Américo Mateus

DELLI - Design Lusófona Lisboa

Lisboa, Portugal

Email: americo.mateus@ulusofona.pt

ORCID:0000-0003-2514-4484

Susana Leonor

UNIDCOM / IADE

Lisboa, Portugal

Email: susana.leonor@universidadeeuropeia.pt

ORCID:0000-0002-3493-7307

Manuel Sequeira

UNIDCOM / IADE

Lisboa, Portugal

Email: manuel.sequeira@universidadeeuropeia.pt

ORCID:0000-0003-0915-3129

Rui Gaio

UNIDCOM / IADE

Lisboa, Portugal

Email: rui.gaio@universidadeeuropeia.pt ORCID:0000-0001-5040-915

Correspondência:

Farley Fernandes

Departamento de Comunicação e Artes

Universidade da Beira Interior

Rua Marquês D'Ávila e Bolama

6201-001 Covilhã

Data de submissão: Janeiro 2018

Data de avaliação: Março 2018

Data de publicação: Julho 2018 